\title{
PRICE BEHAVIOUR OF MAJOR VEGETABLES IN HILL REGION OF NEPAL: AN ECONOMETRIC ANALYSIS
}

\author{
R. Mishra ${ }^{1}$, D. A. Kumar \\ Department of Agricultural Economics, GBPUAT, Pantnagar-263 145, Uttarakhand, India,
}

\begin{abstract}
An attempt has been made to study the price behaviour of major vegetables in hill region of Nepal. The study is based on secondary data on wholesale monthly/weekly arrivals and prices for the period of 2000-01 to 2009-10. The seasonality in wholesale price was analyzed using multiplicative model; the Fourier analysis was used to analyze cyclical variation in wholesale prices and Autoregressive model to study the relationship between market arrival and price of vegetables in market of hill region of Nepal. It was found that during the post-harvest period, the wholesale price ruled very low while during the lean period, the prices were quite high which is due to seasonal and perishable nature of the vegetables. The entire vegetables registered the positive and increasing trend and periodicities of 2 to 3 years in the wholesale price of vegetables. The effect of lagged price on current wholesale price was positively significant and high in magnitude and significant negative response was observed for the relationship between wholesale price and market arrival for all the vegetables in the market of hill region. Therefore, improved market information system is a need of efficient vegetable markets in Nepal in order to enable farmers to make proper production and marketing decisions. Further, Government is required to create market infrastructure facilities like warehousing, processing, transportation, etc. for reducing the variation in prices of vegetables in the market of hill region of Nepal.
\end{abstract}

Key Words: Hill region, nepal, price behaviour, and vegetables.

\section{INTRODUCTION}

Nepal is a landlocked country lying on the southern slope of Himalayas in South Asia between People's Republic of China in North and India in South, North and East. Ecologically, Nepal can be divided into three regions namely the Terai (Plain), the Hills and the Mountains. Agriculture is the engine of development of

\footnotetext{
${ }^{1}$ Corresponding author mail: rozni.mishra13@gmail.com
}

Received: 10.05.2012 
Nepalese Economy which together with forest contributed 33.03 per cent to Gross Domestic Product (GDP) during the fiscal year 2009-10 (Ministry of Agriculture, Nepal 2010). Among horticultural crops, vegetable cultivation is one of the important short seasonal and major crop enterprises of Nepalese agricultural system. Production of vegetables is a traditional custom in Nepalese community, particularly for culinary purpose. It comes under national priority because they are much important as vegetables are less risky, fast growing and best source of income in comparison to other cereal crops and fruits. Further, the importance of vegetables in agricultural economy of Nepal can be very well appreciated in terms of their rising domestic demand, providing better employment and income opportunities to the growers in view of their being labour intensive nature and more remunerative. While domestic demand is steadily rising, the production and supply of vegetables face tremendous uncertainties on several accounts. Their extremely perishable nature, bulkiness, and sensitiveness to climatic conditions results in inability on the part of producers to manage their supply in assembling markets. Seasonal gluts are, therefore, a common phenomenon in assembling markets during normal production seasons.

The market imperfections are also providing disincentive to the growers in increasing vegetable production. The availability of information of quantum of market arrivals and existing prices in different markets help the farmers in adjusting their cropping pattern in such a way that they could sell their produce at a time when the prices are reasonably high in the market. Thus, the price behaviour of vegetables, spatial or temporal, has a definite bearing upon the rationality of the decisions by the growers as well as traders. Therefore, the price behaviour of major vegetables needs to be studied. In view of above situation, the present study was conducted with the main objective to examine the temporal price behaviour of vegetables in the hill region of Nepal. The hill region has the potential for producing seasonal as well as off-seasonal vegetables.

\section{MATERIALS AND METHODS}

The study was based on secondary data collected from Kalimati Fruit and Vegetable Market Development Board and Agro Enterprise Centre, Federation of Nepal Chambers of Commerce and Industry (FNCCI), Kathmandu, Nepal for the period from 2000-01 to 2009-10. This market was selected for the study, being the largest vegetable market in the region in term of vegetable trade which receives daily market arrival around 500 or 600 tons. The major vegetables cultivated in hilly regions of Nepal are tomato, potato, onion, cabbage, cauliflower, etc. The farmers of hilly region have scattered land holdings that are unsuitable for cereals production. Therefore, farmers are more fascinated towards the cultivation of vegetable crops that give higher total yield per unit area per unit time. Vegetables like tomato, cabbage and cauliflower have achieved tremendous popularity over some year due to their two seasons of production. These vegetables are very healthy as they are good source of Vitamins A and C. Although potato and onion are produced once a year in hilly 
region but their consumption is high all over the country. These are the vegetables that arrive in largest quantity in the central market of Capital. Therefore, the major vegetables selected on the basis of arrival in the selected principal regulated market were tomato-local, potato-red, onion-dry, cabbage and cauliflower (Table 1).

The temporal price behaviour of each sample vegetables was studied by computing the seasonal, trend and cyclical variation therein using a multiplicative model of following type:

$$
\mathbf{P}_{\mathrm{t}}=\mathrm{S}_{\mathrm{t}} \times \mathbf{T}_{\mathrm{t}} \times \mathbf{C}_{\mathrm{t}} \times \mathbf{R}_{\mathrm{t}}
$$

where,

$\mathrm{P}_{\mathrm{t}}=$ Time series data on wholesale prices of vegetable (Rs/Qtl);

$\mathrm{S}_{\mathrm{t}}=$ Seasonal fluctuation at time $\mathrm{t}$;

$\mathrm{T}_{\mathrm{t}}=$ Trend value at time $\mathrm{t}$;

$\mathrm{C}_{\mathrm{t}}=$ Cyclic fluctuation at time $\mathrm{t}$; and

$\mathrm{R}_{\mathrm{t}}=$ Irregular fluctuation at time $\mathrm{t}$.

The seasonality or seasonal indices was estimated by classical decomposition through 12 Month Moving Average using monthly average prices. The price series was deseasonalised by dividing it by seasonal indices. Then the trend equations were fitted in deseasonalised data as-

$$
\mathbf{Y}=\mathbf{a}+\mathbf{b T}+\mathbf{U}
$$

Where,

$\mathrm{Y}=$ Deseasonalised prices per month;

$\mathrm{T}=$ Time period in months $(\mathrm{T}=1,2, \ldots \ldots, 120)$;

$\mathrm{a}=$ Slope coefficient;

$\mathrm{b}=$ Regression coefficient; and

$\mathrm{U}=$ Error term.

The trend estimates were tested using t-statistic and the trend values were derived using the trend equation. The Fourier analysis using trigonometric functions was used to uncover the hidden periodicity of the business cycles in a series. The time series data for the period of 9 years (2001-02 to 2009-10) were deseasonalised and detrended as a Fourier series. For analysis 3 periods of 2, 3 and 4 years of length were taken and squared amplitudes were computed for each specific period by findings the Fourier coefficients. The Fourier coefficients $A_{P}$ and $B_{P}$ were computed from above formulae for the trial period $\mathrm{P}(\mathrm{mP}$ is $\mathrm{N}$ or the nearest integer below $\mathrm{N})$ :

$x_{t}=A_{P} \cos \frac{2 \pi t}{P}+B_{F} \sin \frac{2 \pi t}{p}$

Fourier coefficients 
$A_{P}=\frac{\left(2 \sum_{\mathrm{t}=1}^{P}\left[U_{t} \cos \frac{2 \pi t}{P}\right)\right]}{m P}, \quad \mathrm{~B}_{\mathrm{p}}=\frac{\left(2 \sum_{\mathrm{t}=1}^{\mathrm{p}}\left[\mathrm{U}_{\mathrm{t}} \sin \frac{2 n}{\mathrm{~F}}\right)\right]}{\mathrm{mP}}, \quad \mathrm{U}_{\mathrm{t}}=\sum_{\mathrm{r}=1}^{\mathrm{m}} \mathrm{x}_{\mathrm{t}+(\mathrm{r}-1) \mathrm{P}}$

The squared of amplitudes for trial period $\mathrm{P}$ was given as:

$\mathbf{R}_{\mathrm{P}}^{2}=\mathrm{A}_{\mathrm{P}}^{2}+\mathbf{B}_{\mathrm{P}}^{2}$

The hidden periodicities were found by using Schuster test Periodogram analysis. It was used to test the significance of the squared amplitude derived from Fourier analysis. The mean squared amplitude $\left(\mathrm{R}_{\mathrm{m}}^{2}\right)$ was calculated under the assumption that there were no periodic fluctuations i.e. series were random following normal distribution.

According to the test, the probability that the empirical squared amplitude $\left(\mathrm{R}^{2}{ }_{\mathrm{P}}\right)$ was $\mathrm{k}$ times the mean squared amplitude.

$$
\mathbf{R}_{\mathrm{m}}^{2}=\frac{4 \sigma^{2}}{\mathbf{N}} \quad \mathbf{k}=\frac{\mathbf{R}_{\mathrm{p}}^{2}}{\mathbf{R}_{\mathrm{m}}^{2}}
$$

Where, $\sigma^{2}$ is the variance of the original price series

The significant value of $\mathrm{k}$ at 0.05 probability level is 3 . The analysis has been done for each vegetable separately.

The temporal relationship between arrivals of vegetables and prices was analysed in ten year monthly data (2000-01 to 2009-10) using ordinary least square method. Following type of linear functions were estimated to study the relationship:

$$
\begin{aligned}
& A_{t}=a+b P_{t}+u \\
& P_{t}=c+d A_{t}+v
\end{aligned}
$$

where,

$\mathrm{A}_{\mathrm{t}}=$ Market arrival (Qt1.) of vegetable in $\mathrm{t}^{\text {th }}$ month;

$\mathrm{P}_{\mathrm{t}}=$ Wholesale price $\left(\mathrm{Rs} \mathrm{Qtl}^{-1}\right.$.) of vegetable in $\mathrm{t}^{\text {th }}$ month;

a and $\mathrm{c}=$ Slope intercepts ;

$\mathrm{b}$ and $\mathrm{d}=$ Regression coefficients; and

$\mathrm{u}$ and $\mathrm{v}=$ Error terms.

The regression coefficient was tested using t-statistic. In monthly data, only concurrent functions were fitted because vegetables being perishable nature arrive daily in the market in the respective seasons and also due to improvement in market information, farmers are informed of prevailing market price within a day or at most at the gap of 2-3 days. Thus, the arrival of vegetable cannot be a lagged function of price prevailing one month earlier. 
The seasonal relationship between arrivals and wholesale prices of vegetables was analyzed in three years weekly data (2007-08 to 2009-10) using dynamic econometric model namely Autoregressive model. If the model includes one or more lagged values of the dependent variable among its explanatory variables, it is called an autoregressive model. The model can be cited as follows:

$P_{\mathrm{t}}=\mathbf{f}\left(\mathbf{P}_{\mathrm{t}-1}, A_{\mathrm{t}}\right)$

Where,

$\mathrm{P}_{\mathrm{t}}=$ Price of vegetable $\left(\mathrm{Rs} \mathrm{Qtl}^{-1}\right)$ in $\mathrm{t}^{\text {th }}$ week;

$\mathrm{P}_{\mathrm{t}-1}=$ Price of vegetable $\left(\mathrm{Rs} \mathrm{Qt}^{-1}\right)$ in $(\mathrm{t}-1)^{\mathrm{th}}$ week; and

$A_{t}=$ Arrival of vegetable $\left(\operatorname{Rs~Qtl}^{-1}\right)$ in $\mathrm{t}^{\text {th- }}$ week.

The specific linear model involving above three variables and a random term $\mathrm{u}_{\mathrm{t}}$ was used as:

$\mathbf{P}_{\mathrm{t}}=\alpha+\beta \mathrm{P}_{\mathrm{t}-1}+\gamma A_{\mathrm{t}}+\mathrm{u}_{\mathrm{t}}$

Where,

$\alpha=$ Intercept;

$\beta$ and $\gamma=$ Slope coefficients associated with $\mathrm{P}_{\mathrm{t}-1}$ and $\mathrm{A}_{\mathrm{t}}$, respectively; and $\mathrm{u}_{\mathrm{t}}=$ Random term.

The parameters were tested using t-statistic. In this case classical least squares method is not applicable because if an explanatory variable in a regression model is correlated with the stochastic distribution term, the OLS estimators are not only biased but also not even consistent. Further, the serial correlation in the errors, make the estimation problem in the autoregressive model complex. Durbin $\mathrm{h}$ test was applied as proposed for a large sample test of first-order serial correlation in autoregressive model. The d value from Durbin-Watson test was used to calculate $\rho$ as follows:

$$
h=\rho \sqrt{\frac{\mathrm{n}}{1-\mathrm{n}[\operatorname{var}(\gamma)]}}^{F} \quad \rho \approx\left(1-\frac{\mathrm{d}}{2}\right)
$$

where,

$\mathrm{n}=$ Sample size;

var $\mathrm{I}=$ Variance of the lagged price $\left(\mathrm{P}_{\mathrm{t}-1}\right)$ coefficient; and

$\rho=$ Estimate of first-order serial correlation.

Criteria: If $|\mathrm{h}|>1.96$, reject the null hypothesis that $\rho=0$, i.e. there is evidence of first-order autocorrelation in above given autoregressive model. 


\section{RESULTS AND DISCUSSION}

Vegetables are seasonal crops and their production and consequently their supply in the market is subject to natural vagaries. The supply of each vegetable on one hand and the demand for them on the other, at a particular time and market, will determine the wholesale price. The change in determinants of supply and demand over a period of time will affect the price which will lead to seasonality effect in price series that is generally more during off-seasons. The analysis of such seasonal and other components of time series on wholesale prices of vegetables is very important from producers', consumers' and policy makers' stand point. There are four components of price fluctuation viz., seasonal, secular trend, cyclical and irregular variation. The irregular variation has no defined pattern, hence is of no policy importance. Therefore, in the study seasonal movement, secular trend and cyclical movement of prices have been studied.

\section{Seasonality in Prices of Vegetables}

The result pertaining to the seasonal indices of price of all major vegetables are exhibited in table 2.

Tomato-local: Tomato should be sold in fresh form. Storage facility for this crop does not have a significant role. Due to this, it is expected that the price of tomato would register a much higher magnitude in intra year price rise or fall depending on arrivals received in Kalimati Wholesale market. The price of tomatolocal in Hill region shows rising trend from March/April and start decreasing from September/October as the tomato from plain starts coming in the market. The lowest price of tomato-local in hill region was in January/February and highest in the month of August/September

Potato-red: The analysis shows that the prices of potato-red in hill region start rising from March/April till September/October because of high demand of hill potato in plains in the period and by February/March all the local produce gets harvested and arrival decline substantially in hill region. The prices again show declining trend from October/November as the harvesting of early crops starts and the minimum prices are indicated in February/March.

Onion-dry: The analysis shows the prices of onion-dry rise from June/July with maximum in October/November in hill region and prices become less than average from January/February as the onion from plain region starts coming in the market. The minimum price is seen in the month of May/June.

Cabbage: Cabbage is generally winter season crop for mid-hill region while it is summer and rainy season crop for high-hill region. The analysis shows that the prices of cabbage was more than average from June/July to November/December which were lower than average during December/January to May/June, being the main production season. The prices start to increase from June/July in spite of arrival of cabbage from high-hill as the harvesting season in this region is in the month of July/August. This is due to the sticking of wholesale price to previous month price inspite of arrival from high-hills. This revealed that wholesale price of cabbage is 
affected by its lagged price in hill region. Thus, the storage helps prices behave evenly over time through reducing glut in the market and sale in lean period or offseason.

Cauliflower: Cauliflower, a close relative of cabbage, is a delicate crop mainly grown as rainy season crop in high-hill and winter season crop in mid-hill regions. The main harvesting period of cauliflower in hill regions is October/November to March/April Consequently the price indices are below 100 during these months. The maximum price was seen in the month of August/September and minimum in February/March.

\section{Secular Trend in the Prices of Vegetables}

Trend is that component of variation which reveals general direction of change in prices over a period of time. This component is affected by factors inducing changes in demand such as change in population, income, habits, customs, establishment of processing industries, etc. for the commodity concerned. Price trend is also affected by adjustment in supply arising out of development of cold storage and marketing facilities, production techniques and market arrival over a long period. Trend Equations in wholesale prices of major vegetables are estimated after removing seasonality in monthly prices. The equations are estimated on deseasonalised price for 120 months. The results are presented in table 3 .

The table reveals that the trend coefficients were significant for all the vegetables. It is noted in the table that wholesale prices of all the vegetables have been found increasing over time. The table further reveals that the onion-dry prices were rising more rapidly and cauliflower prices with the least rate. The increase in wholesale price of onion-dry might be due to substitution of crop by other more profitable crops by the farmers which cause decrease in supply in the region. The value of coefficient of determination $\left(\mathrm{R}^{2}\right)$ was high for potato-red and onion-dry indicating good fit for trend. The explained variation of price trend of tomato-local and cabbage was only around 19 percent.

\section{Cyclical Fluctuation}

The cycles were the oscillatory movements of the time series with a variable period and amplitude. According to Schumpeter (1939), these cycles are classified as Kondratieff cycles (period $<60$ years), Juglar cycles (period $<10$ years) and Kitchin cycles (period $<40$ months). Nine years deseasonalised and detrended data were analyzed using Fourier analysis followed by Periodogram analysis to estimate the hidden periodicity along with amplitude in the cycles of vegetable prices. Estimated coefficients of Fourier analysis and Periodogram analysis along with Schuster test are presented in table 4.

The table depicts that for tomato-local prices only the value of $\mathrm{k}$ for the trial period of 2 years $(\mathrm{k}=3.06)$ was more than 3 , significant at 5 percent level which showed that prices of tomato-local followed Kitchin cycle having a significant periodicity of 2 years. The results of analysis for potato-red prices indicated that in 
Kalimati market, two year price cycle $(\mathrm{k})$ as obtained which was significant at 5 percent level. The results of Periodogram analysis for onion-dry prices indicated that two-year prices cycle were found to be significant at 5 percent level in Kalimati market. Similarly for cabbage prices the table indicates that the value of $\mathrm{k}$ for the trial period of 3 years $(k=3.15)$ was more than 3 , significant at 5 percent level which showed that cabbage prices followed the Kitchin cycle having periodicity of 3 years. The cauliflower prices also followed the Kitchin cycle having periodicity of 3 years given only the value of $\mathrm{k}$ for the trial period of 3 years $(\mathrm{k}=3.08)$ was more than 3 , significant at 5 percent level.

\section{Temporal Relationship}

Conceptually, arrival of a commodity in the market rises as its market price increases, ceteris-paribus. Further, with the increase in market arrivals, the market price of the commodity declines, ceteris-paribus. In other words, the market arrival is expected to be an increasing function of the market price, whereas the market price is expected to be the decreasing function of market arrival. The result of analysis of inter-relationship between arrival and price pertaining to major vegetables are presented in table 5 and 6 .

The table 5 reveals that except for potato-red and onion-dry, all the other major vegetables responded negatively to the rise in market arrivals thereof, i.e., the hypothesis of price decrease with increase in arrivals and vice-versa stand accepted. There was a positive but insignificant response of potato-red arrival to its price. However, the significant positive response of onion-dry to its price appeared to be contributed by factors like integration between hill and plain markets; arrival being received in hill markets from hill as well as plains, having different market seasons; and relatively less perishability of the commodity. The variation explained in tomatolocal wholesale price by market arrival was 13 percent in Kalimati market of hill region. However, in any of the other vegetables not much variation in price was attributable to variation in market arrival.

The table 6 implies that except for potato-red and onion-dry, market arrival responded negatively to rise in wholesale price of all other major vegetables. The relation appeared to be a spurious one and advised not to be used. In fact, in case of vegetables, highly perishable commodities, growers had no option but to sell the product immediately after harvest and as the market arrival rises, prices ought to decline, ceteris paribus. Thus, the arrival of vegetables in the market depends on variables like perishability, distance from market and similar factors rather than on market price.

\section{Seasonal Relationship}

The seasonal relationship between the market arrival, current price and lagged

price of major vegetables in hill region were based on the weekly statistics for a period of three years viz., 2007-08 to 2009-10. The econometric model known as 
autoregressive model was used to analyze the relationship between current price, lagged price and the market arrival of vegetables.

As the serial correlation in the error term make the estimation in autoregressive model rather complex, a large-sample test of first-order serial correlation known as $h$ statistic was applied. The result of $h$ statistic revealed that there was an absence of positive autocorrelation (Table 8). Table 7 depicted that the positive response of lagged price of all vegetables to its current wholesale price was highly significant. The maximum change in current price due to one week lag price was observed in potato-red and onion-dry. Further, the current price of all the vegetables responded negatively to its market arrival. Among the vegetables, the change in current price of tomato-local was observed maximum with the change in its market arrival. The current price variation explained through lagged price and market arrival were 70, 95 $, 66,81$ and 67 percent in case of tomato-local, potato-red, onion-dry, cabbage and cauliflower, respectively. The results revealed that grower's decision to sell the produce was also based on current market arrival and lag weekly price of vegetables. This indicated the presence of imperfection in marketing of vegetables as the traders used the previous week price as a guide for setting the current price of the vegetables, instead of current market arrival and demand.

\section{CONCLUSION}

The results found from this research showed reasonably a high degree of seasonality in the wholesale prices of all the vegetables. However, continuity in seasonality in prices was affected because of arrival of vegetables in Kalimati Wholesale Market from different agro-climatic regions due to which seasonality got smoothened. It was observed that vegetable crops such as potato-red and onion-dry are yearly crops whereas tomato-local, cabbage and cauliflower are produced even twice in a year. In addition, many vegetable crops have the same harvesting season due to which the substitutability or complementarily of one vegetable affects the price of the other. The trend analysis showed that all the vegetable crops had a positive increasing trend in prices of vegetables during the study period which indicated that irrespective of increase in supply the price also increased, due to faster rate of growth in demand than supply. The wholesale price series of both tomatolocal and potato-red in Kalimati market followed the Kitchin cycle having significant periodicity of 2 years while remaining vegetables viz., onion-dry, cabbage and cauliflower followed the Kitchin cycle of 3 years periodicity. The irregular component, however, is difficult to predict and it differed for prices series among various selected crops.

The relationship between wholesale price and market arrival of all the major vegetables except potato-red and onion-dry showed a negative relationship whereas the vice-versa relationship for potato-red and onion-dry were spurious. This might be due to the dependency of current price upon lagged price of onion-dry which may be 
due to perishable nature of vegetables, lack of storage facilities and market information. Further, it was observed that there was absence of positive autocorrelation. Therefore, the effect of lagged price on current wholesale price was positive, high in magnitude and significant for all the selected vegetables. This indicated imperfection in marketing of vegetables in Kalimati Wholesale market as the traders used the previous week price as guide for setting the current price of the vegetable, instead of current market arrival and demand. Therefore, it may be concluded from the study that Government is required to pay attention in building the improved market information system i.e. able to disseminate up to date and timely market information on the regular basis so as to make proper production and marketing decision. Further, market infrastructure facilities like warehousing, transportation, processing, etc should be established to help the growers in storage of their produce in the glut season and then take advantages of off-season prices in order to eliminate the seasonality in market arrivals of vegetables and this also minimize the price volatility of the vegetables.

\section{REFERENCES}

Acharya, S. S. and Agarwal, N. L. 2004. Agricultural Marketing in India. $4^{\text {th }}$ Edition. Oxford and IBH Publishing Company Private Limited, New Delhi, India.

Alemayehu, M and Atteri, B. R. 2002. Price Behavior of Ginger and Garlic in Delhi Wholesale Market. Indian Journal of Agricultural Marketing., 16(1): 45-50.

Balamurugan, V. and Ramanathan. 2008. Pattern of Market Arrivals and Market Integration of Groundnut in Regulated Markets, Tamil Nadu. Indian Journal of Agricultural Marketing, 22(3): 89-98.

Bhandari, P., Karl, E. and Weber, L. 2001. Disposal and Price Behavior of Paddy in Chitwan Valley, Nepal. The Economic Journal of Nepal, 22(1): 18-32.

Dhaliwal, T., Kaur, L., Rangi, P. S. and Singh, N. 2005. An Econometric Analysis of Tomato Arrivals and Prices in Punjab. Indian Journal of Agricultural Marketing, 19(3): 61-67.

Kainth, G. S. and Mehra, P. L. 2003. Seasonality Pattern of Market Arrival and Prices of Potatoes in Punjab. Indian Journal of Agricultural Marketing, 2(1):113-120.

Kumar, N. R., Pandey, N. K. and Rana, R. K. 2003. Price Behavior of Potatoes in Meerut Wholesale Market. Journal of Indian Potato Association, 30(1): 203-204.

Kumar, V., Sharma, H. R. and Singh, K. 2005. Behavior of Market Arrivals and Prices of Selected Vegetable Crops: A Study of Four Metropolitan Markets. Agricultural Economics Research Review, 18(2): 271-290.

Shrestha, B. (2008). Off-Season Vegetables Marketing Channels of Small Growers: A Case of Yamphant, Tanahun, Nepal. Retrived March 10, 2010 from http://www.larensteinUniversity.org 
Table 1: Market Arrivals (Qtl) of Fruits and Vegetables in Kalimati Wholesale Market of Nepal (2007-08 to 2009-10)

\begin{tabular}{lcccccc}
\hline \multicolumn{1}{c}{ Particulars } & $\mathbf{2 0 0 7 - 0 8}$ & Percent & $\mathbf{2 0 0 8 - 0 9}$ & Percent & $\mathbf{2 0 0 9 - 1 0}$ & Percent \\
\hline Fruits and others & 407368.19 & 20.02 & 368723.31 & 20.79 & 292331.35 & 16.56 \\
Total Vegetables & 1627747.43 & 79.98 & 1405166.18 & 79.21 & 1472932.70 & 83.44 \\
Total & 2035115.62 & 100 & 1773889.49 & 100 & 1765264.05 & 100 \\
Tomato-Local & 204433.02 & 12.56 & 185567.60 & 13.21 & 161874.00 & 10.99 \\
Potato-Red & 238579.70 & 14.66 & 233477.00 & 16.62 & 239317.00 & 16.25 \\
Onion-Dry & 125589.50 & 7.72 & 113736.00 & 8.09 & 151352.20 & 10.28 \\
Cabbage & 136323.98 & 8.38 & 129778.50 & 9.24 & 112224.10 & 7.62 \\
Cauliflower & 204093.75 & 12.54 & 153957.55 & 10.96 & 251912.30 & 17.10 \\
Subtotal & 909019.95 & 55.85 & 816516.65 & 58.11 & 916679.69 & 62.23 \\
Other vegetables & 718727.48 & 44.15 & 588649.53 & 41.89 & 556253.10 & 37.77 \\
\hline Total & & & $\mathbf{1 0 0}$ & & $\mathbf{1 0 0}$ \\
\hline
\end{tabular}

Source: Kalimati Fruit and Vegetable Market Development Board (KFVMDB), 2010.

Table 2: Seasonal Price Indices of Major Vegetables in Hill Region of Nepal

\begin{tabular}{lcccccc}
\hline Months & Tomato-local & Potato-red & Onion & Cabbage & Cauliflower \\
\hline Apr/May & 82.60 & 72.70 & 84.00 & 68.87 & 83.00 \\
May/June & 86.68 & 90.19 & 75.11 & 67.25 & 90.93 \\
June/July & 129.45 & 102.40 & 84.77 & 106.77 & 109.66 \\
July/Aug & 130.92 & 113.78 & 94.80 & 111.81 & 119.93 \\
Aug/Sept & 154.21 & 126.96 & 110.40 & 123.56 & 162.68 \\
Sept/Oct & 130.61 & 137.95 & 119.38 & 139.60 & 156.08 \\
Oct/Nov & 97.18 & 134.38 & 131.13 & 146.47 & 119.23 \\
Nov/Dec & 74.58 & 108.95 & 121.42 & 126.95 & 95.28 \\
Dec/Jan & 72.62 & 92.83 & 104.82 & 91.23 & 75.04 \\
Jan/Feb & 71.63 & 79.46 & 99.81 & 71.26 & 65.57 \\
Feb/Mar & 91.50 & 67.90 & 94.16 & 66.64 & 60.60 \\
Mar/Apr & 82.49 & 72.46 & 83.26 & 63.62 & 64.95 \\
\hline Not:All & & & & &
\end{tabular}

Note: All values are in term of indices 
Table 3: Estimated Trend Equations in Wholesale Prices of Major Vegetables in Hill Region of Nepal

(Prices in Rs per Quintal)

\begin{tabular}{l|c|c|c|c|c}
\hline Vegetables & $\begin{array}{c}\text { Intercept } \\
\text { (a) }\end{array}$ & $\begin{array}{c}\text { Regression } \\
\text { Coefficient (b) }\end{array}$ & t-value & $\begin{array}{c}\text { Standard Error of } \\
\text { Coefficient SE(b) }\end{array}$ & $\mathbf{R}^{\mathbf{2}}$ \\
\hline Tomato-local & 1281.614 & $9.869^{* * *}$ & 5.385 & 1.833 & 0.197 \\
Potato-red & 688.381 & $11.091 * * *$ & 11.899 & 0.927 & 0.548 \\
Onion-dry & 1019.726 & $12.197 * * *$ & 10.899 & 1.119 & 0.502 \\
Cabbage & 527.661 & $7.895 * * *$ & 5.283 & 1.494 & 0.191 \\
Cauliflower & 1894.231 & $4.912 * * *$ & 3.465 & 1.418 & 0.092 \\
\hline
\end{tabular}

Note: $* * *$ significant at 1 percent level of probability $(\mathrm{t}-\mathrm{value}=2.58)$

Table 4: Periodogram Analysis of Wholesale Prices of Major Vegetables in Kalimati Market of Hill Region of Nepal

\begin{tabular}{|c|c|c|c|c|c|}
\hline \multirow[t]{2}{*}{ Period (N) } & \multicolumn{2}{|c|}{ Fourier Coefficients } & \multirow{2}{*}{$\begin{array}{c}\text { Squared } \\
\text { Amplitude } \\
\mathrm{R}_{\mathrm{p}}^{2}\end{array}$} & \multirow{2}{*}{$\begin{array}{c}\text { Mean Squared } \\
\text { Amplitude } \\
\mathrm{R}_{\mathrm{m}}^{2}\end{array}$} & \multirow{2}{*}{$\begin{array}{c}\text { Ratio } \\
\text { K }\end{array}$} \\
\hline & $A_{p}$ & $\mathrm{~B}_{\mathrm{p}}$ & & & \\
\hline \multicolumn{6}{|l|}{ Tomato-Local } \\
\hline 2 & -275.43 & 0 & 75866.21 & 24792.88 & $3.06^{* *}$ \\
\hline 3 & 101.10 & -87.63 & 17900.22 & & 0.70 \\
\hline 4 & 125.10 & 36.65 & 16993.23 & & 0.68 \\
\hline \multicolumn{6}{|l|}{ Potato-Red } \\
\hline 2 & 205.22 & 0 & 42115.73 & 13991.94 & $3.01 * *$ \\
\hline 3 & 109.88 & -83.77 & 19091.02 & & 1.36 \\
\hline 4 & 30.69 & -67.72 & 5527.87 & & 0.40 \\
\hline \multicolumn{6}{|l|}{ Onion-Dry } \\
\hline 2 & 221.71 & 0 & 49158.14 & 16277.53 & $3.02 * *$ \\
\hline 3 & -180.19 & 67.80 & 32536.23 & & 1.99 \\
\hline 4 & -72.9 & -6.74 & 5359.83 & & 0.30 \\
\hline \multicolumn{6}{|l|}{ Cabbage } \\
\hline 2 & -102.64 & 0 & 10535.84 & 12484.59 & 0.80 \\
\hline 3 & 161.29 & 115.37 & 39326.44 & & $3.15^{* *}$ \\
\hline 4 & -31.51 & 143.97 & 21720.24 & & 1.74 \\
\hline \multicolumn{6}{|l|}{ Cauliflower } \\
\hline 2 & 166.99 & 0 & 27885.66 & 26889.70 & 1.03 \\
\hline 3 & 241.30 & 157.24 & 82952.60 & & $3.08^{* *}$ \\
\hline 4 & -47.21 & -30.35 & 3149.90 & & 0.11 \\
\hline
\end{tabular}

Note: $* *$ Significant at 1 percent level of probability $(\mathrm{k}$-value $=3.00)$

Table 5: Estimated Regression Equations of Wholesale Price on Market Arrival 
of Major Vegetables in Kalimati Market of Hill Region of Nepal (Prices in Rs per Quintal)

\begin{tabular}{l|c|c|c|c|c|c}
\hline Vegetables & $\begin{array}{c}\text { Intercept } \\
\mathbf{( a )}\end{array}$ & $\begin{array}{c}\text { Regression } \\
\text { Coefficient } \\
\mathbf{( b )}\end{array}$ & $\mathbf{t}$-value & $\begin{array}{c}\text { Standard } \\
\text { Error of } \\
\text { Coefficient } \\
\mathbf{S E}(\mathbf{b})\end{array}$ & $\begin{array}{c}\text { Coefficient of } \\
\text { Determination } \\
\left.\mathbf{( R}^{2}\right)\end{array}$ & $\begin{array}{c}\text { Correlation } \\
\text { Coefficient } \\
(\mathbf{r})\end{array}$ \\
\hline Tomato-Local & 2637.45 & $-0.583^{* * *}$ & -4.310 & 0.135 & 0.136 & -0.369 \\
Potato-Red & 1220.42 & 0.079 & 0.641 & 0.123 & 0.003 & 0.058 \\
Onion-Dry & 1242.68 & $0.610^{* * *}$ & 2.610 & 0.234 & 0.054 & 0.233 \\
Cabbage & 1242.04 & $-0.236^{*}$ & -1.869 & 0.126 & 0.029 & -0.17 \\
Cauliflower & 2387.61 & -0.165 & -1.357 & 0.122 & 0.015 & -0.124 \\
\hline
\end{tabular}

Note: $* * *$ Significant at 1 percent level of probability $(\mathrm{t}-\mathrm{value}=2.58)$

*Significant at 10 percent level of probability $(\mathrm{t}$-value $=1.65)$

Table 6: Estimated Regression Equations of Market Arrival on Wholesale Price of Major Vegetables in Kalimati Wholesale Market of Hill Region of Nepal (Prices in Rs per Quintal)

\begin{tabular}{lcccccc}
\hline Vegetables & $\begin{array}{c}\text { Intercept } \\
\mathbf{( a )}\end{array}$ & $\begin{array}{c}\text { Regression } \\
\text { Coefficient } \\
\mathbf{( b )}\end{array}$ & t-value & $\begin{array}{c}\text { Standard } \\
\text { Error of } \\
\text { Coefficient } \\
\mathbf{S E}(\mathbf{b})\end{array}$ & $\begin{array}{c}\text { Coefficient of } \\
\text { Determination } \\
\mathbf{( R}^{2} \mathbf{)}\end{array}$ & $\begin{array}{c}\text { Correlation } \\
\text { Coefficient } \\
\mathbf{( r )}\end{array}$ \\
\hline $\begin{array}{l}\text { Tomato- } \\
\text { Local }\end{array}$ & 1800.03 & $-0.233^{* * *}$ & -4.31 & 0.054 & 0.136 & -0.369 \\
Potato-Red & 1634.60 & 0.044 & 0.64 & 0.068 & 0.003 & 0.058 \\
Onion-Dry & 699.30 & $0.089^{* *}$ & 2.61 & 0.034 & 0.054 & 0.233 \\
Cabbage & 1031.76 & $-0.122^{*}$ & -1.86 & 0.064 & 0.029 & -0.17 \\
Cauliflower & 1327.34 & -0.093 & -1.35 & 0.068 & 0.015 & -0.124 \\
\hline
\end{tabular}

Note: $* * *$ Significant at 1 percent level of probability $(\mathrm{t}-\mathrm{value}=2.58)$

$* *$ Significant at 5 percent level of probability $(\mathrm{t}$-value $=1.96)$

*Significant at 10 percent level of probability $(\mathrm{t}$-value $=1.65)$ 
Table 7: Estimated Regression Equations of Wholesale Price on Lagged Price and Market Arrival of Major Vegetables in Kalimati Wholesale Market of Hill Region of Nepal (Prices in Rs per Quintal)

\begin{tabular}{|c|c|c|c|c|c|c|c|c|}
\hline \multirow[t]{2}{*}{ Vegetable } & \multirow[t]{2}{*}{$\begin{array}{c}\text { Intercept } \\
(\sigma)\end{array}$} & \multicolumn{2}{|c|}{ Regression Coefficient of } & \multicolumn{2}{|c|}{$\begin{array}{l}\text { Standard Error of } \\
\text { Regression } \\
\text { Coefficient }\end{array}$} & \multicolumn{2}{|c|}{ t-value } & \multirow[t]{2}{*}{$\mathbf{R}^{2}$} \\
\hline & & $\begin{array}{c}\text { Lagged } \\
\text { Price }(\beta)\end{array}$ & $\begin{array}{c}\text { Market } \\
\text { Arrival }(Y)\end{array}$ & $\begin{array}{l}\mathrm{SE} \\
(\beta)\end{array}$ & $\operatorname{SE}(Y)$ & $\beta$ & $\gamma$ & \\
\hline Tomato-local & 1472.02 & $0.667 * * *$ & $-2.01 * * *$ & 0.057 & 0.461 & 11.791 & -4.361 & 0.70 \\
\hline Potato-red & 176.344 & $0.966^{* * *}$ & $-0.24 * *$ & 0.019 & 0.113 & 15.852 & -2.135 & 0.95 \\
\hline Onion-dry & 651.117 & $0.806^{* * *}$ & $-0.75 * * *$ & 0.049 & 0.476 & 16.370 & -2.596 & 0.66 \\
\hline Cabbage & 292.345 & $0.904^{* * *}$ & $-0.57^{* *}$ & 0.036 & 0.394 & 25.15 & -1.984 & 0.81 \\
\hline Cauliflower & 901.912 & $0.755^{* * *}$ & $-0.85 * * *$ & 0.049 & 0.266 & 15.704 & -3.224 & 0.67 \\
\hline
\end{tabular}

Note: $* * *$ Significant at 1 percent level of probability (t-value $=2.58) * *$ Significant at 5 percent level of probability $(\mathrm{t}$-value $=1.96)$

Table 8: Test of Serial Autocorrelation in Establishing Relationship of Wholesale Price with Lagged Price and Market Arrival of Major Vegetables

\begin{tabular}{lccccc}
\hline Vegetables & $\begin{array}{c}\text { Standard Error of } \\
\text { Regression } \\
\text { Coefficient of } \\
\text { Lagged Price }\end{array}$ & $\begin{array}{c}\text { Variance of Regression } \\
\text { Coefficient of Lagged } \\
\text { Price }\end{array}$ & $\begin{array}{c}\text { d- } \\
\text { statistic }\end{array}$ & $\begin{array}{c}\text { Estimate of } \\
\text { First-Order } \\
\text { Serial } \\
\text { Correlation }\end{array}$ & $\begin{array}{c}\text { h- } \\
\text { statistic }\end{array}$ \\
\hline Tomato-local & 0.057 & $(\boldsymbol{p})]$ & $(\boldsymbol{P})$ & \\
Potato-red & 0.019 & 0.00324 & 1.779 & 0.1105 & 1.805 \\
Onion-dry & 0.049 & 0.00361 & 1.720 & 0.0140 & 1.710 \\
Cabbage & 0.036 & 0.00241 & 1.845 & 0.0770 & 1.136 \\
Cauliflower & 0.049 & 0.00129 & 2.120 & -0.060 & -0.794 \\
\hline
\end{tabular}

Note: Sample size $(\mathrm{n})=143$

Rejection of null hypothesis $(\rho=0)$ when $|\mathrm{h}|>1.96$ at 5 percent probability 